\title{
PELATIHAN PEMBUATAN PERAHU BERBAHAN FRP (FIBERGLASS REINFORCED PLASTIC) UNTUK PENGRAJIN PERAHU NELAYAN DI DESA GISIK CEMANDI, SIDOARJO, JAWA TIMUR
}

\author{
Putu Arta Wibawa $^{1 *}$, Aang Wahidin ${ }^{1}$, Fathulloh ${ }^{1}$, Putu Sindhu Asmara', Budianto ${ }^{1}$, Sumardiyono $^{1}$ \\ ${ }^{1}$ Politeknik Perkapalan Negeri Surabaya \\ email: putuarta@ppns.ac.id
}

diterima tanggal : 10 Agustus 2018 disetujui tanggal : 20 November 2018

\begin{abstract}
Abstrak
Pelatihan pembuatan perahu berbahan FRP (Fiberglass Reinforced Plastic) untuk pengrajin perahu nelayan di Desa Gisik Cemandi melibatkan dua Mitra pengrajin perahu nelayan setempat. Sampai sebelum pelaksanaan pelatihan, kompetensi Mitra hanya terbatas pada pembangunan perahu nelayan berbahan kayu dengan design yang relative sama. Dengan mempertimbangkan semakin sulitnya memperoleh kayu dan semakin besarnya peluang pengembangan perahu berbahan FRP di Desa Gisik Cemandi dan sekitarnya maka diperlukan usaha-usaha untuk membangun kompetensi pengrajin perahu setempat dalam hal pembangunan perahuberbahan FRP. Peningkatan kompetensi pengrajin perahu melalui program Pengabdian Masyarakat ini dilakukan dalam bentuk pelatihan pembangunan perahu berbahan FRP. Pelatihan diawali dengan pengenalan dan pemahaman gambar standar design perahu, pengenalan bahan FRP dan safety procedure, pembuatan cetakan, pembuatan perahu FRP sampai dengan finishing.
\end{abstract}

Kata kunci : Pengrajin Perahu, Perahu FRP, Gisik Cemandi.

\begin{abstract}
Training on constructing boats made of FRP (Fiberglass Reinforced Plastic) for traditional boat builder in Gisik Cemandi Village, Sidoarjo involved two local boatyards. Until recently, the Partner's competencieswere limited to the construction of wooden fishing boats with relatively the same design. By considering the increasing difficulties of obtaining wood and the increasing opportunities for developing FRP boats in Gisik Cemandi Village and its surroundings, efforts are needed to build the competencies of local boat builder in terms of building FRP-based boats. Increasing the competencies of traditional boat builder through the Community Service program was carried out in the form of FRP boat building training. The training begins with the introduction and understanding of boat design standards, introduction of FRP materials and safety procedures, mold making, FRP boat start from manufacturing to finishing.
\end{abstract}

Keyword : FRP Boat, Traditional Boatbuilder, Gisik Cemandi

\section{PENDAHULUAN}

\subsection{Analisis Situasi}

Desa Gisik Cemandi merupakan salah satu desa nelayan di Kabupaten Sidoarjo, Jawa Timur. Sekitar $71 \%$ dari total 1013 penduduk di desa ini berprofesi sebagai nelayan, sehingga sektor perikanan menjadi penggerak utama perekonomian di daerah ini. Keberadaan Tempat Pelelangan Ikan (TPI) Sedati yang berada tepat pada jalur sungai di desa Gisik Cemandi juga sangat mendukung aktivitas penangkapan ikan oleh nelayan setempat. Disamping itu, lokasinya yang tepat berada di belakang Bandar Udara Internasional Juanda menjadikan daerah ini juga menjadi daerah wisata bagi Kabupaten Sidoarjo, sehingga pasar untuk hasil tangkapan nelayan setempat relatif terjamin.

Sebagai alat pendukung utama aktivitas penangkapan ikan, nelayan di desa Gisik Cemandi menggunakan perahu berbahan kayu dengan total panjang berkisar antara 10 meter sampai dengan 13 
meter, seperti yang terlihat pada Gambar 1. Dengan mempertimbangkan kekuatan dan keawetan kayu maka kayu Jati menjadi pilihan utama dari nelayan setempat untuk menjamin umur perahu yang lebih panjang. System penggerak utama perahu menggunakan motor tempel diesel atau bensin yang dihubungkan dengan baling-baling poros panjang. Sedangkan alat tangkap yang digunakan umumnya berupa jaring gillnet.

Hasil wawancara dengan pengrajin perahu di desa Gisik Cemandi menunjukkan bahwa kebutuhan akan perahu nelayan sebagai alat utama aktivitas penangkapan ikan di daerah pesisir timur Kabupaten Sidoarjo ini masih cukup tinggi. Bapak Heri, salah satu pengrajin perahu sekaligus Mitra pada program PKM ini, mengungkapkan bahwa beliau menerima pesanan pembuatan perahu hingga kurang lebih 11 unit setiap tahunnya. Tahun 2017, hingga bulan Mei saja, beliau sudah mengerjakan 5 unit perahu, dan saat wawancara dilakukan pada awal Juni 2017, beliau sedang mengerjakan pesanan 4 unit perahu sampai bulan Juli 2017. Disamping pesanan pembuatan perahu baru, jasa reparasi terhadap perahu-perahu yang sudah beroperasi juga relatif tinggi, mengingat ada sekitar 148 unit perahu di desa Gisik Cemandi sendiri, sedangkan jika memperhitungkan dua desa disekitarnya yang juga tergantung pada pengrajin perahu dari Gisik Cemandi, jumlah perahu total bisa mencapai 400 unit perahu.

Terlepas dari masih tingginya permintaan akan perahu nelayan, pengrajin perahu setempat menghadapi permasalahan dari segi biaya produksi yang semakin tinggi yang kemudian berpengaruh pada harga perahu yang mereka tawarkan. Kendala utama yang dihadapi pengrajin perahu menurut pengrajin lainnya, Bapak Iswandi, adalah sulitnya memperoleh kayu, khususnya kayu Jati, sebagai material utama pembuatan perahu. Kayu jati yang mereka gunakan saat ini umumnya berasal dari perkebunan rakyat di daerah Malang, Probolinggo atau daerah lainnya di Jawa Timur. Dari segi kualitas, kayu Jati dari perkebunan rakyat tidak sebaik kayu Jati hutan dari PERHUTANI, namun dari segi harga jauh lebih murah. Harga kayu Jati dari perkebunan rakyat menurut Bapak Heri bisa mencapai 6 Juta rupiah per meter kubik, sedangkan harga kayu Jati kualitas 1 dari PERHUTANI dapat mencapai harga 18 Juta rupiah. Tingginya harga kayu ini menyebabkan tingginya harga perahu baru bagi nelayan.

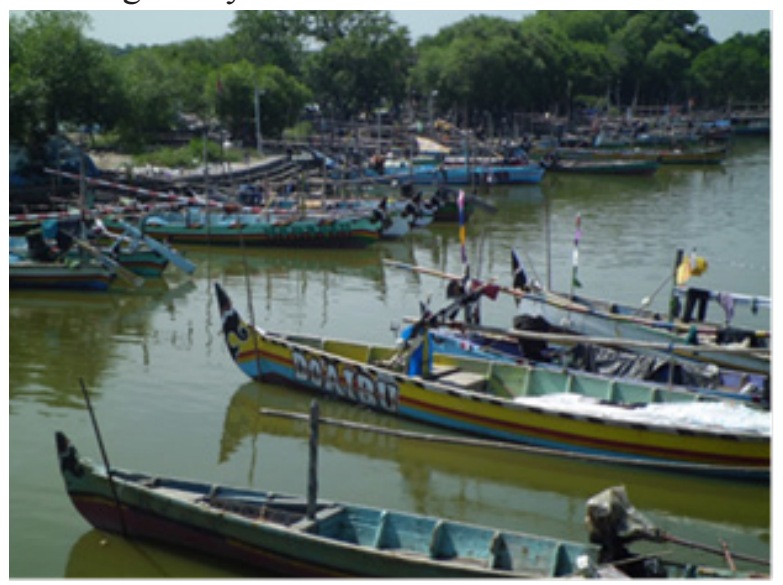

Gambar 1. Perahu nelayan di TPI Sedati



Gambar 2. Perahu FRP di Desa Gisik Cemandi

Permasalahan kesulitan pengadaan material utama pembuatan perahu/kapal ikan berbahan kayu sebenarnya sudah menjadi masalah nasional dalam waktu lebih dari sepuluh tahun terakhir (Wibawa, 2016). Permasalahan ini yang kemudian mendasari kebijakan yang diambil oleh Kementerian Kelautan dan Perikanan (KKP) dalamhal modernisasi armada perikanan rakyat untuk memasyarakatkan penggunakan material alternatif sebagai pengganti kayu dalam pembangunan kapal penangkap ikan. Pada program pengadaan 1000 unit kapal ikan untuk nelayan Indonesia tahun 2010 sampai dengan tahun 2014 (KKP, 2014), kelompok nelayan penerima bantuan diberikan pilihan jenis material yang digunakan untuk kapal mereka yaitu kayu atau fiberglass. Namun untuk pengadaan kapal ikan bantuan pada tahun 20162017 yang berjumlah sekitar 3.325 unit (Saragih, 2016), semua type kapal ikan bantuan mulai 30GT sampai dengan perahu/kapal ikan dibawah 5GT harus menggunakan material FRP (KKP, 2016) 
Jika melihat perkembangan teknologi pembangunan kapal ikan di dunia, salah satu yang menjadi perhatian adalah penggunaan material alternatif sebagai pengganti kayu yang semakin sulit diperoleh (Anmarkrud, 2009) . Dalam hal ini, penggunaan material composite termasuk Fiberglass Reinforcement Plastic (FRP) sudah menjadi pilihan utama di berbagai negara khususnya untuk kapal-kapal kecil dengan panjang di bawah 24 meter (Valdemarsen, 2001; Anmarkrud, 2009).

Di Indonesia perkembangan pemanfaatan FRP sebagai pengganti kayu untuk material utama pembuatan kapal-kapal kecil khususnya untuk kapal-kapal nelayan semakin terlihat di berbagai daerah (Gudmundsson and Davy, 2006; Wibawa, 2014). Kesulitan memperoleh kayu dalam beberapa tahun belakangan dan berbagai kelebihan yang dimiliki oleh FRP sebagai material pembangunan kapal menyebabkan perahu FRP semakin banyak digunakan oleh nelayan-nelayan di Indonesia, khususnya untuk kapal-kapal kecil dibawah 5GT (Wibawa, 2016).

Hasil wawancara dan pengamatan yang dilakukan di daerah sekitar TPI Sedati menunjukkan ada satu perahu nelayan yang terbuat dari FRP seperti yang terlihat pada Gambar 2. Hal ini membuka kemungkinan berkembangnya penggunaan perahu FRP bagi nelayan setempat di masa yang akan datang. Beberapa keuntungan penggunaan FRP sebagai perahu seperti konstruksi yang lebih ringan dan tidak diperlukan perawatan yang rutin seperti perahu kayu akan mempercepat kemungkinan perahu FRP semakin banyak digunakan oleh nelayan di Desa Gisik Cemandi dan sekitarnya.

\subsection{Permasalahan Mitra}

Permasalahan dalam hal pengadaan kayu secara nasional untuk pembangunan dan reparasi perahu/kapal nelayan yang terbuat dari kayu menjadi alasan dari kebijakan Kementerian Kelautan dan Perikanan untuk memasyarakatkan penggunaan material FRP bagi kapal-kapal ikan di Indonesia. Sebagai konsekuensi dari kebijakan ini dan untuk mengantisipasi semakin sulitnya memperoleh material kayu yang berkualitas di masa yang akan datang, maka diperlukan

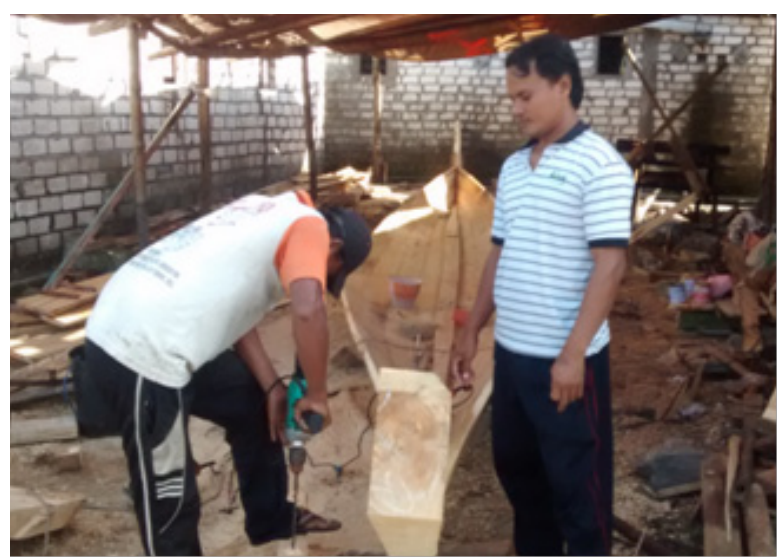

Gambar 3. Galangan perahu milik Mitra PKM

transfer teknologi bagi galangan kapal traditional beserta pengrajin kapal dalam hal pembangunan kapal/perahu penangkap ikan berbahan material alternatif FRP.

Peluang berkembangnya perahu/kapal berbahan fiberglass ini juga sebaiknya segera diantisipasi oleh pengrajin perahu di Desa Gisik Cemandi dan sekitarnya dengan menambah ketrampilan mereka dalam pembuatan perahu/ kapal dengan material-material alternatif termasuk Fiberglass. Namun, dari hasil wawancara awal dengan pengrajin perahu setempat, mereka tidak memiliki kemampuan untuk membangun perahu berbahan selain kayu. Perahu fiberglass yang digunakan oleh salah satu nelayan di Gisik Cemandi, seperti yang terlihat pada Gambar 2, dibuat di galangan perahu di daerah Probolinggo, Jawa Timur

Di sisi lain, seperti umumnya pengrajin kapal tradisional di Indonesia, ketrampilan pembuatan perahu nelayan yang dimiliki pengrajin kapal di Gisik Cemandi diperoleh secara turun menurun dengan tanpa ditunjang oleh pendidikan formal keteknikan pada bidang perkapalan. Metode pembangunan kapal/perahu yang digunakan juga bersifat tradisional dengan bentuk perahu yang relatif sama karena diturunkan dari generasi sebelumnya, seperti yang terihat pada Gambar 3. Design perahu yang digunakan selama berpuluhpuluh tahun di desa ini adalah design lambung perahu yang dikenal dengan istilah lokal sebagai perahu "Kolekan". Design ini memiliki kesamaan dengan perahu "Golekan" yang banyak dijumpai di Pulau Madura, yang kemudian diperkirakan 
menyebar ke berbagai daerah di Jawa Timur (Samodra, 2010). Dengan tanpa didukung oleh kemampuan membaca gambar kapal standar, maka akan sulit bagi pengrajin perahu ini untuk membuat perahu/kapal yang memiliki design yang berbeda dari yang sudah biasa dikerjakan selama ini.

Berdasarkan uraian diatas, dua permasalahan utama yang dimiliki oleh pengrajin perahu di Desa Gisik Cemandi untuk dapat memanfaatkan peluang berkembangnya pasar perahu/kapal berbahan FRP adalah sebagai berikut:

1. Pengrajin perahu belum memiliki kompetensi dalam hal metode pembangunan perahu/kapal secara standar berdasarkan gambar kerja yang memungkinkan pengrajin setempat membuat perahu sesuai design pesanan.

2. Pengrajin perahu belum memiliki kompetensi dalam hal pembangunan perahu/kapal menggunakan bahan Fiberglass Reinforced Plastic (FRP)

Dengan dua permasalahan utama yang dihadapi ini, akan sulit bagi pengrajin perahu di Desa Gisik Cemandi untuk bisa memanfaatkan peluang pasar jika di masa yang akan datang semakin banyak nelayan setempat yang menggunakan perahu berbahan FRP, atau lebih jauh lagi menutup peluang yang lebih besar bagi pengrajin perahu setempat untuk mengambil peluang dari pengadaan kapal-kapal ikan FRP oleh Kementerian Kelautan dan Perikanan secara nasional.

Hasil diskusi dengan Mitra menunjukkan bahwa ada keinginan yang sangat besar dari kedua Mitra untuk dapat meningkatkan kompetensi mereka dalam hal pembangunan perahu/kapal, termasuk dalam pembuatan perahu/kapal berbahan FRP, sehingga mereka dapat menerima pesanan perahu/kapal dengan design dan material yang berbeda dibandingkan dengan perahu yang biasa mereka kerjakan saat ini.

\section{METODE PELAKSANAAN}

Pelaksanaan PKM pada usaha kecil galangan kapal kayu di Desa Gisik Cemandi dilakukan dalam bentuk pelatihan kepada pengarjin perahu dalam hal pembangunan kapal berbahan material FRP.
Bentuk pelatihan secara umum akan disampaikan dalam dua metode, yaitu teori dan praktik. Materi pelatihan yang disampaikan dalam bentuk teori dimaksudkan untuk menambah wawasan pengrajin dalam hal pembuatan kapal secara modern dan pengenalan material FRP secara umum. Sedangkan materi yang disampaikan dengan praktik bertujuan untuk membentuk practical skill dari pengrajin dalam hal pembangunan kapal FRP. Detail kegiatan yang akan dilakukan terdiri dari beberapa aktivitas sesuai Tabel 1 berikut:

Tabel 1. Aktivitas untuk PKM pengrajin perahu

\begin{tabular}{|c|c|c|}
\hline No & Aktivitas & Bentuk Kegiatan \\
\hline 1 & \begin{tabular}{|l} 
Praktik \\
pembuatan \\
Moulding \\
Kapal FRP \\
\end{tabular} & $\begin{array}{l}\text { Pengrajin diajarkan cara } \\
\text { pembuatan cetakan } \\
\text { kapal FRP }\end{array}$ \\
\hline 2 & \begin{tabular}{|l} 
Pengenalan \\
material FRP
\end{tabular} & $\begin{array}{l}\text { Pengrajin dikenalkan } \\
\text { dengan material } \\
\text { penyusun FRP, metode } \\
\text { pelapisan material FRP, } \\
\text { metode penyimpanan } \\
\text { material dan prosedur } \\
\text { Kesehatan dan } \\
\text { Keselamatan Kerja } \\
\text { (K3) untuk pengerjaan } \\
\text { produk berbahan FRP } \\
\end{array}$ \\
\hline 3 & $\begin{array}{l}\text { Praktik } \\
\text { pembuatan } \\
\text { kapal FRP }\end{array}$ & $\begin{array}{l}\text { Pengrajin diajarkan } \\
\text { tahapan pembangunan } \\
\text { kapal FRP mulai } \\
\text { persiapan sampai } \\
\text { dengan finishing kapal } \\
\end{array}$ \\
\hline 4 & $\begin{array}{l}\text { Praktik } \\
\text { Perbaikan dan } \\
\text { perawatan } \\
\text { kapal FRP }\end{array}$ & $\begin{array}{l}\text { Pengrajin diajarkan } \\
\text { metode perawatan dan } \\
\text { perbaikan kerusakan } \\
\text { pada lambung kapal FRP }\end{array}$ \\
\hline
\end{tabular}

Seluruh aktivitas pelatihan dilaksanakan di galangan perahu milik Mitra, dengan melibatkan kedua Mitra dan tenaga kerjanya yang berjumlah 8 orang pengrajin perahu. Waktu pelatihan disesuaikan dengan waktu kerja Mitra sehingga tidak mengganggu aktivitas pengrajin dalam menyelesaikan pesanan perahu dari nelayan. Setelah program pengabdian selesai, maka perahu yang dihasilkan akan disumbangkan kepada kelompok nelayan setempat sebagai usaha untuk memperkenalkan perahu berbahan FRP kepada nelayan di desa Gisik Cemandi dan sekitarnya. 


\section{HASIL DAN PEMBAHASAN}

Pelaksanaan Pelatihan Pembuatan Perahu Berbahan FRP (Fiberglass Reinforced Plastic) untuk Pengrajin Perahu Nelayan di Desa Gisik Cemandi, Kecamatan Sedati, Kabupaten Sidoarjo, Jawa Timur telah dilaksanakan pada awal bulan Nopember 2018dengan melibatkan pihak Mitra,

Agar pelaksanaan pelatihan berjalan efisien dan efektif, pembuatan cetakan dilakukan di kampus PPNS dengan melibatkan mahasiswa dan teknisi bengkel non-metal, seperti yang terlihat pada Gambar 4. Walaupun cetakan telah dibuat di kampus, namun proses pembuatan cetakan dan pemahaman gambar lines plan tetap dikenalkan pada saat pelatihan di lokasi Mitra.

Proses pelatihan pembuatan perahu berbahan FRP dimulai dari pengenalan proses pembuatan cetakan perahu FRP yang terbuat dari kayu. Dilanjutkan dengan proses persiapan cetakan sebelum dilapisi dengan lapisan awal Gel Coat. Proses persiapan cetakan dilakukan dengan melakukan pelapisan Release Agent berupa Mirror Glaze Wax dan PVA ke permukaan cetakan. Seperti yang terlihat pada Gambar 5, semua peserta terlibat aktif dalam pelapisan Wax dan PVA pada permukaan cetakan.

Tahap selanjutnya dalam pelatihan pembuatan perahu FRP untuk pengrajin kapal di Gisik Cemandi adalah pelapisan Gel Coat. Sebelum pelapisan Gel Coat pada permukaan cetakan, peserta dikenalkan metode persiapan dan pencampuran Gel Coat, yang meliputi komposisi antara Gel Coat dan Cobalt, penambahan pigmen warna, dan proses pencampuran unsur-unsur diatas. Pelapisan Gelcoat dilakukan pada seluruh permukaan cetakan oleh peserta pelatihan.

Segera setelah permukaan Gel Coat kering dilanjutkan dengan pelapisan serat gelas pada cetakan. Peserta dikenalkan dan dilatih untuk mengaplikasikan serat gelas dan resin pada permukaan cetakan dengan metode hand lay up yaitu aplikasi secara manual dengan menggunakan bantuan kuas roll. Langkah-langkah laminasi, persyaratan sambungan antar laminasi dan urutan laminasi diajarkan kepada peserta pelatihan dengan praktek langsung pada cetakan seperti yang terlihat pada Gambar 6 .



Gambar 4. Pembuatan rangka cetakan perahu

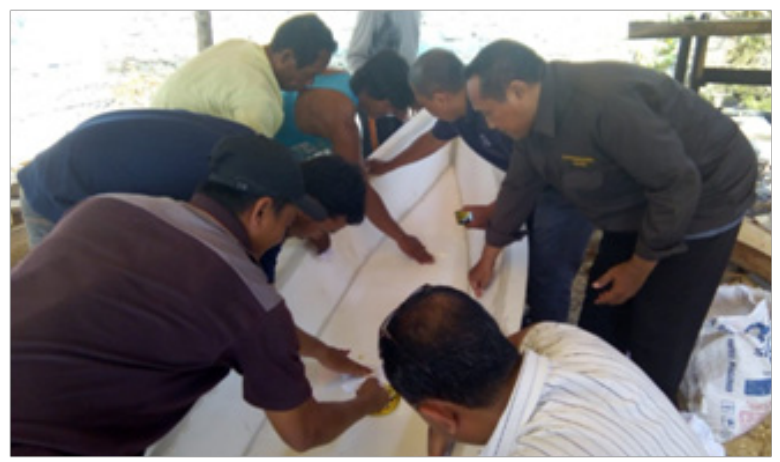

Gambar 5. Pelapisan Release Agent pada cetakan

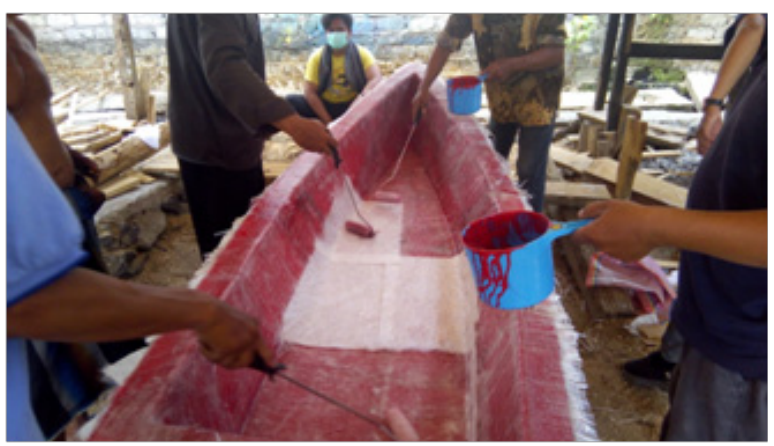

Gambar 6.Laminasi serat gelas oleh peserta

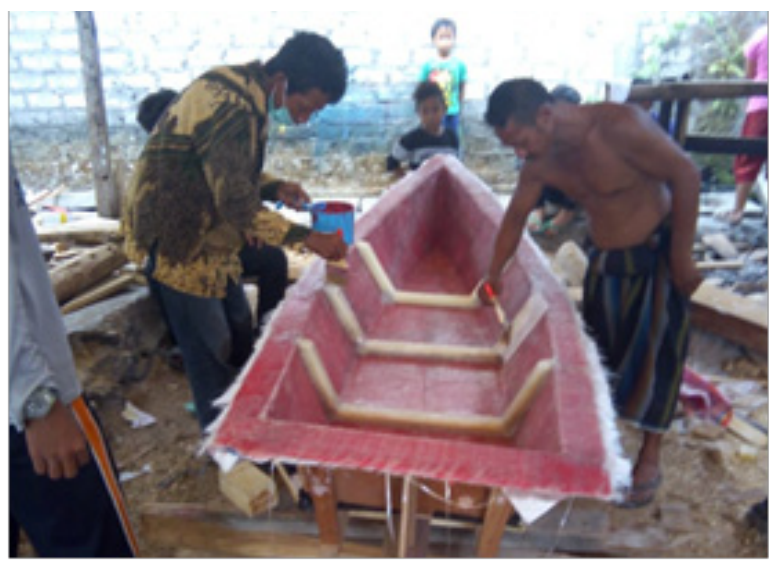

Gambar 7. Pelapisan gading perahu FRP 
Langkah selanjutnya dari proses pembuatan perahu FRP untuk pelatihan pembangunan perahu FRP di Gisik Cemandi adalah pemasangan penguat perahu. Segera setelah lambung kapal kering, maka proses pembuatan perahu FRP dilanjutkan dengan pemasangan gading perahu. Pemasangan gading perahu FRP diawali dengan pemasangan Polyurethane pada lambung kapal. Peserta diperkenalkan dengan metode pembentukan gading yang terbuat dari polyurethane. Peserta pelatihan juga dikenalkan dengan bentuk-bentuk gading yang dapat digunakan oleh peserta jika membangun sebuah kapal FRP. Termasuk penggunaan pipa $\mathrm{PVC}$, kayu ataupun penggunaan gading berongga untuk lambung.

Tahapan berikutnya dalam pemasangan gading pada kapal FRP adalah pelapisan Polyurethane dengan beberapa lapis serat gelas. Peserta pelatihan juga dikenalkan dengan proses pelapisan gading, khususnya terkait metode pelapisan yang tepat untuk pembuatan gading kapal untuk menghindari terjadinya cacat-cacat pada lapisan FRP yang mungkin terjadi pada saat pemasangan gading perahu FRP. Gambar berikut menunjukkan prlapisan gading oleh peserta pelatihan.

Sebagai tahapan akhir dari pelatihan pembangunan perahu FRP untuk pengrajin perahu nelayan di Gisik Cemandi adalah pelepasan produk perahu dari cetakan dan uji coba terhadap perahu FRP, Uji coba dilakukan pada kolam tambak di dekat galangan Mitra, seperti terlihat pada Gambar 8 dan 9.

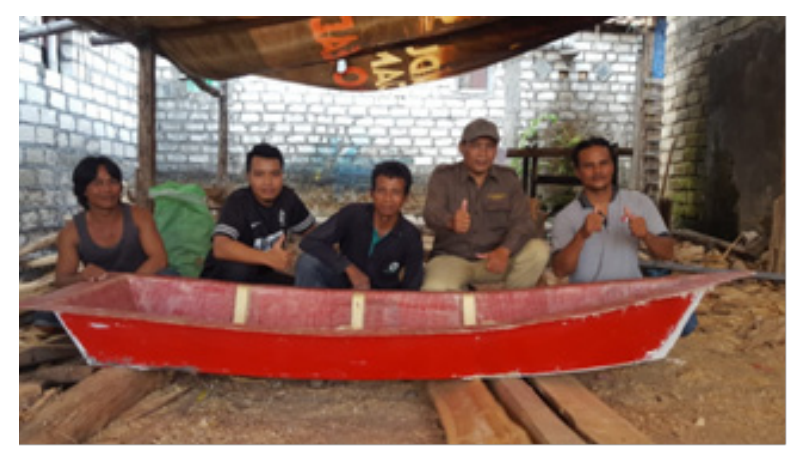

Gambar 8. Laminasi serat gelas oleh peserta

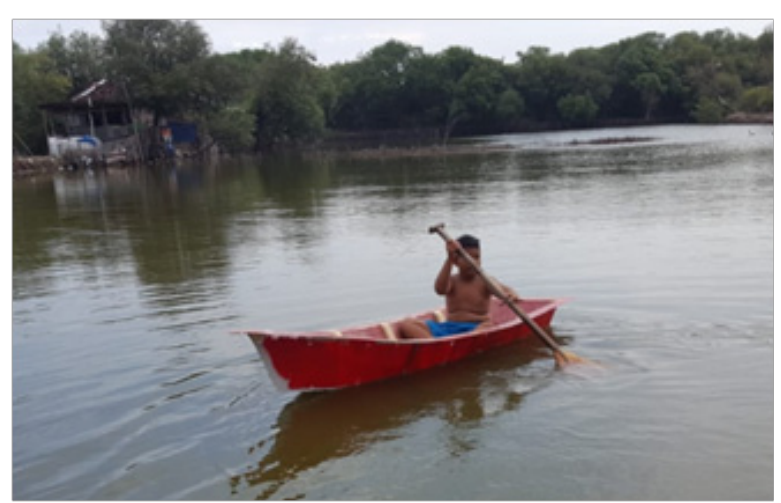

Gambar 9. Laminasi serat gelas oleh peserta

\section{KESIMPULAN}

Beberapa kesimpulan yang dapat diambil dari kegiatan Pengabdian Pelatihan Pembuatan Perahu Berbahan FRP (Fiberglass Reinforced Plastic) untuk Pengrajin Perahu Nelayan di Desa Gisik Cemandi, Kecamatan Sedati, Kabupaten Sidoarjo, Jawa Timur adalah sebagai berikut:

1. Terdapat peluang pengembangan kapal berbahan FRP bagi masyarakat nelayan di sekitar Desa Gisik Cemandi yang dapat dimanfaatkan oleh pengrajin kapal kayu di daerah ini.

2. Pelatihan pembuatan perahu FRP telah dilakukan dengan hasil yang baik dan memberikan pengalaman produksi kepada pengrajin kapal kayu di daerah Gisik Cemandi, Juanda, Sidoarjo.

3. Pengrajin kapal kayu di Desa Gisik Cemandi memiliki kemampuan yang dapat dikembangkan untuk membangun kapal berbahan FRP.

\section{DAFTAR PUSTAKA}

[1] Anmarkrud, T. 2009. Fishing Boat Construction: 4. Building an Undecked Fiberglass Reinforced Plastic Boat, FAO Fisheries and Aquaculture Technical Paper. No. 507, Roma

[2] Gudmundsson, A. and Davy, D. (2006), Boatbuilding after the tsunami: Experiences in boat-building in tsunami-affected countries, Bay of Bengal News, pp. 13-15, Sept.

[3] KKP. 2014. Laporan Kinerja Kementerian Kelautan dan Perikanan Tahun 2010 2014. Kementerian Kelautan dan Perikanan 
Indonesia.

[4] KKP. 2016. Keputusan Kuasa Pengguna Anggaran Direktorat Jenderal Perikanan Tangkap no: B.6281/DJPT/PI.220S2/ VII/2016 tentang Petunjuk Teknis Bantuan Sarana Penangkapan Ikan di Direktorat Jenderal Perikanan Tangkap Tahun Anggaran 2016. Kementerian Kelautan dan Perikanan Indonesia.

[5] Samodra. 2009. Traditional Boatbuilding in Indonesia; A Social and Technological Study of Current Practice and a Proposal for Appropriate Future Development.Disertasi. Newcastle University, United Kingdom

[6] Saragih,S.2016.Lelangproyek3.325kapalikan KKP paling cepat Maret 2016. http://industri. bisnis.com/read/20160217/99/519720/lelangproyek-3.325-kapal-ikan-kkp-paling-cepatmaret-2016. Diakses tanggal 1 Juni 2017.

[7] Valdemarsen, J.W. (2001), Technological Trends in Capture Fisheries, Ocean and Coastal Management, Vol.44, pp.635-651

[8] Wibawa, P.A. 2014. Wood vs FRP, Sustainable Material for Indonesian Fishing Vessels Based on Fishers' Perspectives. Proceeding on The 9th International Conference on Marine Technology 2014. 24 - 26 Oktober 2014. Surabaya, Indonesia

[9] Wibawa, P.A. 2016. Sustainable Fishing Vessel Development by Prioritising Stakeholders Engagement in Indonesian Small-Scale Fisheries. Disertasi. Newcastle University, United Kingdom. 
Halaman ini sengaja dikosogkan 